\title{
A revised lithostratigraphy for the Palaeogene - lower Neogene of the Danish North Sea
}

\author{
Poul Schiøler, Jan Andsbjerg, Ole R. Clausen, Gregers Dam, Karen Dybkjær, Lars Hamberg, \\ Claus Heilmann-Clausen, Lars E. Kristensen, lain Prince and Jan A. Rasmussen
}

Intense drilling activity following the discovery of the Siri Field in 1995 has resulted in an improved understanding of the siliciclastic Palaeogene succession in the Danish North Sea sector (Fig. 1). Many of the new wells were drilled in the search for oil reservoirs in sand bodies of Paleocene-Eocene age. The existing lithostratigraphy was based on data from a generation of wells that were drilled with deeper stratigraphic targets, with little or no interest in the overlying Palaeogene sediments, and thus did not adequately consider the significance of the Palaeogene sandstone units in the Danish sector. In order to improve the understanding of the distribution, morphology and age of the Palaeogene sediments, in particular the economically important sandstone bodies, a detailed study of this succession in the Danish North Sea has recently been undertaken. An important aim of the project was to update the lithostratigraphic framework on the basis of the new data.
The project was carried out at the Geological Survey of Denmark and Greenland (GEUS) with participants from the University of Aarhus, DONG E\&P and Statoil Norway, and was supported by the Danish Energy Agency. Most scientific results cannot be released until September 2006, but a revised lithostratigraphic scheme may be published prior to that date. Formal definition of new units and revision of the lithostratigraphy are in preparation.

All of the widespread Palaeogene mudstone units in the North Sea have previously been formally established in Norwegian or British wells, and no reference sections exist in the Danish sector. As the lithology of a stratigraphic unit may vary slightly from one area to another, Danish reference wells have been identified during the present project, and the lithological descriptions of the formations have been expanded to include the appearance of the units in the Danish sector.
Fig. 1. Map showing the study well data base superposed on an isochore map of the Lista Formation. The Lista Formation thickens towards the northern part of the mapped area; this thickening is mainly due to the presence of sandstone bodies within the Siri Canyon.

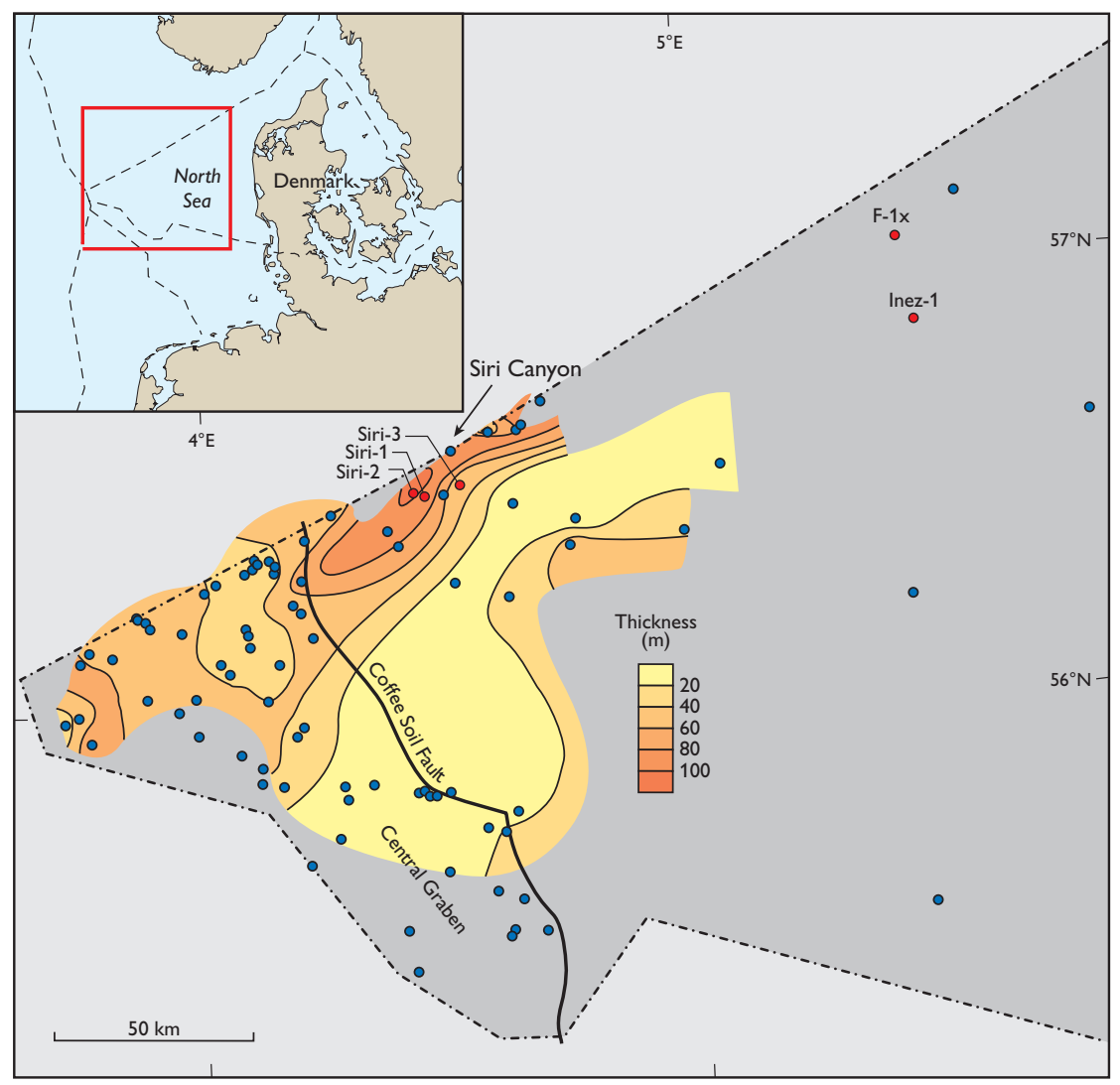


Many of the sandstone bodies recently discovered in the Danish sector have a limited spatial distribution and were sourced from other areas than their contemporaneous counterparts in the Norwegian and British sectors. These sandstone bodies are therefore defined as new lithostratigraphic units in the Danish sector, and are assigned Danish type and reference sections.

There is a high degree of lithological similarity between the Palaeogene-Neogene mudstone succession from Danish

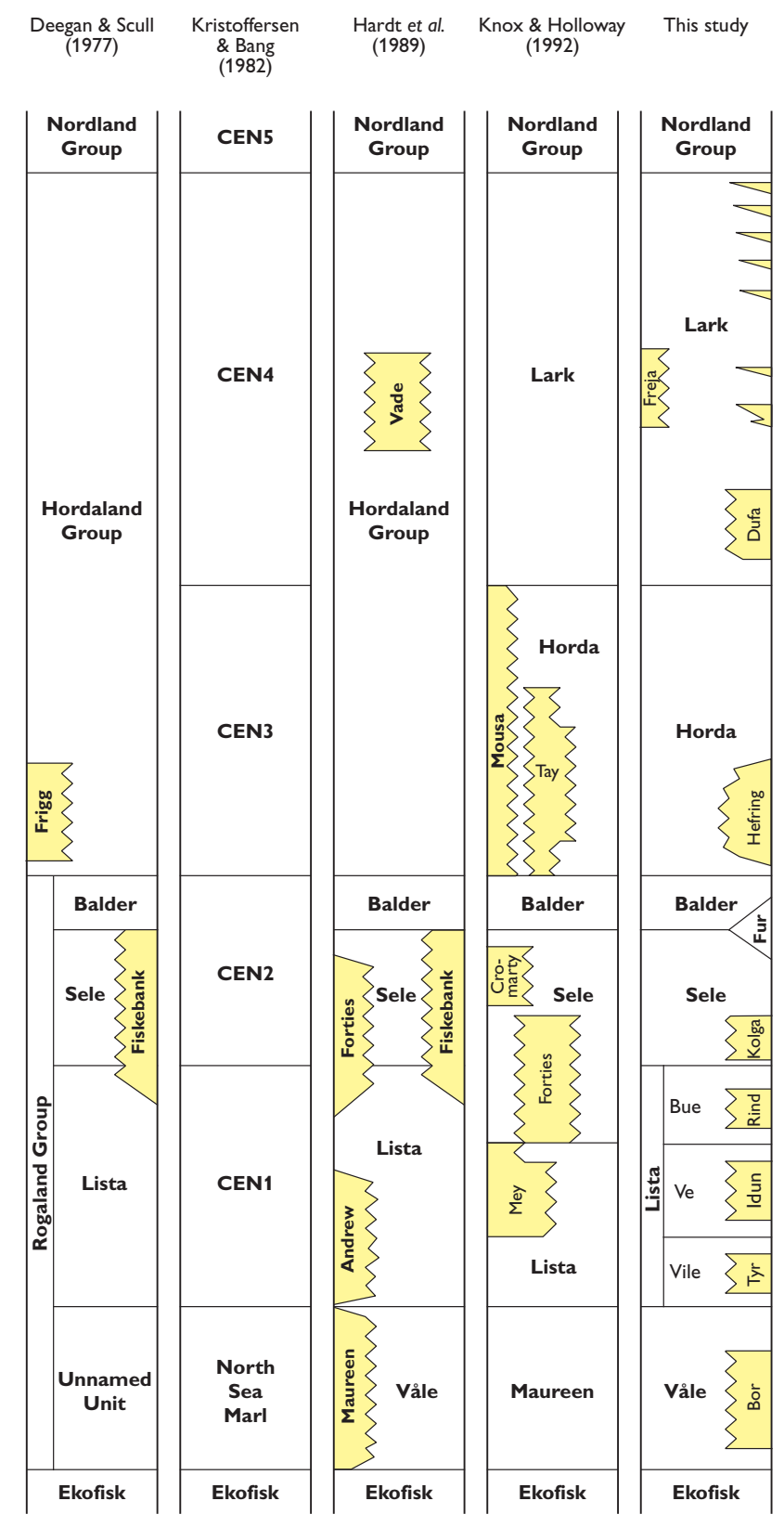

Fig. 2. Diagram showing the correlation between key lithostratigraphic schemes for the Central Graben and eastern North Sea. White: mudstone units. Yellow: sandstone units. Names in bold indicate units of formation or group rank. offshore boreholes and that from onshore exposures and boreholes, and some of the mudstone units indeed seem identical. However, in order to acknowledge the traditional distinction between offshore and onshore stratigraphic nomenclature, the two sets of nomenclature are kept separate herein.

In recent years oil companies operating in the North Sea have developed various in-house lithostratigraphic charts for the Paleocene-Eocene sand and mudstone successions in the Danish and Norwegian sectors. A number of informal lithostratigraphic units have been adopted and widely used. In the present project, these units have been formally defined and described, maintaining their original names whenever feasible, with the aim of providing an unequivocal nomenclature for the Palaeogene - lower Neogene succession in the Danish sector. It has not been the intention to establish a sequence stratigraphic model for this succession in the North Sea; the reader is referred to the comprehensive works of Michelsen (1993), Neal et al. (1994), Mudge \& Bujak (1994, 1996a, b), Michelsen et al. (1995, 1998), Danielsen et al. (1997) and Rasmussen (2004).

\section{Methodology}

The multidisciplinary project integrates biostratigraphic results from palynology and micropalaeontology with results from sedimentological studies, petrophysical log interpretation and conventional seismic interpretation, in an attempt to identify, describe and correlate lithological units. The lithostratigraphy proposed is based on analysis of petrophysical logs from more than 80 wells (Fig. 1) and studies of cuttings samples and core sections. Lithostratigraphic well correlation is supported by results from biostratigraphic analysis of 29 wells encompassing both palynological and micropalaeontological data. This analysis has established a detailed succession of first downhole occurrences of biostratigraphical events which are of crucial importance for well correlation and age determination in the region. Resulting well correlations have been matched with results from interpretation of key seismic sections.

\section{A revised lithostratigraphy}

An important outcome of the project is a revised lithostratigraphic chart for the siliciclastic Palaeogene - lower Neogene succession of the Danish North Sea (Fig. 2). The chart is based on the subdivision proposed by Deegan \& Scull (1977), but incorporates subsequent improvements by Hardt et al. (1989) and Knox \& Holloway (1992).

The revised lithostratigraphy presented in Fig. 2 has its genetic base at the top of the Chalk Group (Ekofisk For- 
mation). The top is at the mid-Miocene unconformity, a basinwide erosion surface that separates the Oligocene to Middle Miocene Hordaland Group from the overlying Middle Miocene to Recent Nordland Group.

The succession is subdivided into seven formations containing eleven new members. The Våle, Lista, Sele, Fur, Balder, Horda and Lark Formations of previous lithostratigraphic schemes are adequate for subdividing the Danish sector at formation level and are retained herein with expanded lithological descriptions. The five first-mentioned formations constitute the Rogaland Group of early Selandian (Late Paleocene) to earliest Eocene (pre-classical Ypresian) age, and the Horda and Lark Formations constitute the Hordaland Group of Ypresian (Early Eocene) to early Serravallian (Middle Miocene) age.

\section{Rogaland Group}

The Våle Formation (Hardt et al. 1989) consists of light grey to greenish grey marlstones and is retained largely unchanged from its original description.

The Lista Formation (Deegan \& Scull 1977) is subdivided into three new mudstone members (Vile, Ve and Bue). The predominantly light to dark grey mudstones of the Vile and Bue Members are separated by the greenish, bluish to red coloured mudstones of the Ve Member.

The Sele Formation (Deegan \& Scull 1977) overlies the Lista Formation; the boundary is placed where laminated dark grey to black mudstones overlie the light to dark grey, smectitic, non-laminated mudstones of the Bue Member. This boundary definition differs from that used by Knox \& Holloway (1992), who placed the Lista-Sele boundary at the base of the Bue Member as recognised here (Fig. 2). Incidentally, the Lista-Sele boundary as originally defined coincides with the Paleocene-Eocene boundary recently approved by the International Commission of Stratigraphy, at the conspicuous ${ }^{13} \mathrm{C}$ isotope excursion in Chron C24r.

The Balder Formation is retained largely unchanged from its original description by Deegan \& Scull (1977).

The Fur Formation (Pedersen \& Surlyk 1983) is characterised by interbedded diatomite and tuffs and has been recognised in one Norwegian and three Danish offshore wells by Thomsen \& Danielsen (1995) at a similar stratigraphic level to that of the Sele and Balder Formations. It is therefore included in the North Sea lithostratigraphic chart (Fig. 2).

\section{Hordaland Group}

The Horda and Lark Formations of Knox \& Holloway (1992) are introduced in the Danish sector for the basinal mudstones that overlie the Balder Formation. The Horda
Formation consists of greenish-grey to greyish-green fissile mudstone, whereas the Lark Formation comprises greenishgrey to dark brown non-fissile mudstones. The transition from the Horda to the Lark Formation is characterised by a significant increase in gamma ray response.

\section{Sandstone members}

Eight discrete sandstone members have been recognised in the Palaeogene - lower Neogene mudstone succession (Fig. 2). The lower five of these occur exclusively in the Siri Canyon, a $20 \mathrm{~km}$ wide and up to $200 \mathrm{~m}$ deep erosional depression that truncates reflectors in the Chalk Group (Fig. 1; Hamberg et al. 2005). The Bor Member is a sandstone unit in the Vale Formation. Three sandstone members occur in the Lista Formation and are named Tyr, Idun and Rind. The Sele and Horda Formations each contain sandstone units for which the names Kolga and Hefring Members are proposed, respectively. The Hefring Member occurs in an area south of the Siri Canyon. Two sandstone members (Dufa and Freja) are present in the Lark Formation. The Dufa Member occurs in the north-eastern part of the Danish sector, around the wells F-1X and Inez-1 (Fig. 1); the Freja Member occurs above the Siri Canyon, south of the Siri-1 well (Fig. 1).

\section{Rogaland Group sandstones: reservoir facies}

The economically important Paleocene-Eocene oil reservoir sandstones of the Rogaland Group are situated at the mouth of, and within, the Siri Canyon (Fig. 1). The sandstones occur as in situ sediment bodies deposited by gravity flows and as remobilised, injected sandstones (Hamberg et al. 2005). Although the sandstone bodies occur at different stratigraphic levels within the Rogaland Group, they are strikingly uniform. The sandstones are quartzose and very fine- to finegrained, well sorted and rich in glaucony with a greenish grey colour. The sandstone bodies appear massive and structureless with primary sedimentary structures preserved only in their basal part. Individual sandstones may be up to $100 \mathrm{~m}$ thick but are usually much thinner. Identification and correlation of individual sandstone members are feasible by means of 3D seismic data, with support from borehole logs and high-resolution biostratigraphy. An example of results from such an integrated correlation in the lower part of the Siri Canyon is shown in Fig. 3. 


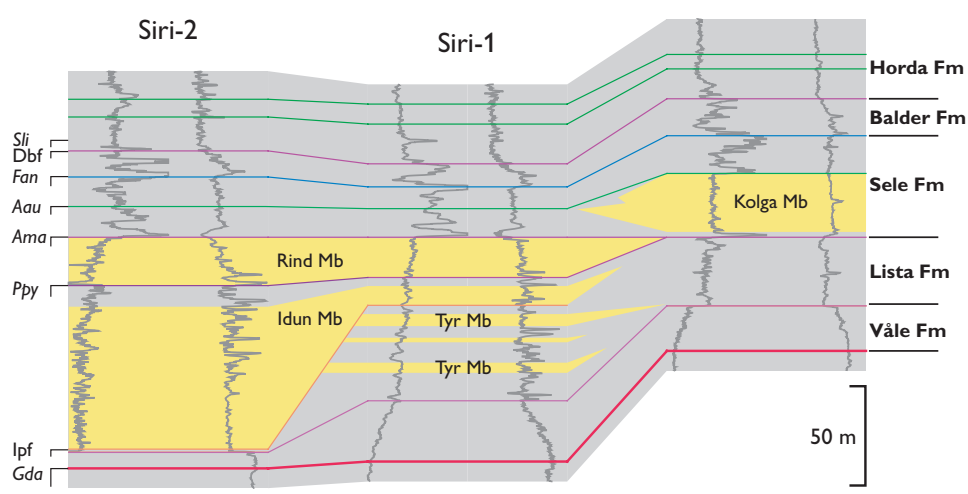

Fig. 3. Correlation diagram of the Rogaland Group in the lower part of the Siri Canyon (well locations shown in Fig. 1). Horizontal distance not to scale. In this section the Tyr Member consists of three sandstone beds separated by mudstone layers. The Idun Member cuts deeply into the underlying Lista Formation. Key biostratigraphic downhole events are shown to the left. Sli, Subbotina linaperta; Dbf, decrease in benthic foraminifera; Fan, influx of Fenestrella antiqua; Aau, Apectodinium augustum; Ama, Alisocysta margarita; Ppy, common Palaeoperidinium pyrophorum; Ipf, increase in planktonic foraminifera; Gda, Globoconusa daubjergensis.

\section{Acknowledgements}

This work was made possible through grants from the Danish Energy Authority, under the Energy Research Programme 2000. DONG E\&P is thanked for access to lithostratigraphic data from Siri Canyon wells.

\section{References}

Danielsen, M., Michelsen, O. \& Clausen, O.R. 1997: Oligocene sequence stratigraphy and basin development in the Danish North Sea sector based on $\log$ interpretations. Marine and Petroleum Geology 14, 931-950.

Deegan, C.E. \& Scull, B.J. (compilers) 1977: A standard lithostratigraphic nomenclature for the Central and Northern North Sea. Institute of Geological Sciences Report 77/25; Norwegian Petroleum Directorate Bulletin 1, $36 \mathrm{pp}$

Hamberg, L., Dam, G., Wilhelmson, C. \& Ottesen, T.G. 2005: Paleocene deep-marine sandstone plays in the Siri Canyon, offshore Denmark southern Norway. In: Doré, A.G. \& Vining, B.A. (eds): Petroleum geology: North West Europe and global perspectives. Proceedings of the 6th Petroleum Geology Conference, 1185-1198. London: Geological Society.

Hardt, T., Holtar, E., Isaksen, D., Kyllingstad, G., Lervik, K.S., Lycke, A.S. \& Tonstad, K. 1989: Revised Tertiary lithostratigraphic nomenclature for the Norwegian North Sea. In: Isaksen, D. \& Tonstad, K. (eds): A revised Cretaceous and Tertiary lithostratigraphic nomenclature for the Norwegian North Sea. Norwegian Petroleum Directorate Bulletin $\mathbf{5}, 35-55$.

Knox, R.W.O'B. \& Holloway, S. 1992: Paleogene of the Central and Northern North Sea. In: Knox, R.W.O'B. \& Cordey, W.G. (eds): Lithostratigraphic nomenclature of the UK North Sea, 133 pp. Nottingham: British Geological Survey.

Kristoffersen, F.N. \& Bang, I. 1982: Cenozoic excl. Danian limestone. In: Michelsen, O. (ed.): Geology of the Danish Central Graben. Danmarks Geologiske Undersøgelse Serie B 8, 62-71.

Michelsen, O. 1993: Stratigraphic correlation of the Danish onshore and offshore Tertiary successions based on sequence stratigraphy. Bulletin of the Geological Society of Denmark 41, 145-161.

Michelsen, O., Danielsen, M., Heilmann-Clausen, C., Jordt, H., Laursen, G. \& Thomsen, E. 1995: Occurrence of major sequence stratigraphic boundaries in relation to basin development in Cenozoic deposits of the southeastern North Sea. In: Steel, R.J. et al. (eds): Sequence stratigraphy on the Northwest European margin. Norsk Petroleum Forening Special Publication 5, 415-427.

Michelsen, O., Thomsen, E., Danielsen, M., Heilmann-Clausen, C., Jordt, H. \& Laursen, G. 1998: Cenozoic sequence stratigraphy in the eastern North Sea. In: de Graciansky, P.-C. et al. (eds): Mesozoic and Cenozoic sequence stratigraphy of European basins. Society of Economic Paleontologists and Mineralogists Special Publication 60, 91-118.

Mudge, D.C. \& Bujak, J.P. 1994: Eocene stratigraphy of the North Sea basin. Marine and Petroleum Geology 11, 166-181.

Mudge, D.C. \& Bujak, J.P. 1996a: Paleocene biostratigraphy and sequence stratigraphy of the UK central North Sea. Marine and Petroleum Geology 13, 295-312.

Mudge, D.C. \& Bujak, J.P. 1996b: An integrated stratigraphy for the Paleocene and Eocene of the North Sea. In: Knox, R.W.O'B., Corfield, R.M. \& Dunay, R.E. (eds): Correlation of the Early Paleogene in Northwest Europe. Geological Society Special Publication (London) 101, 91-113.

Neal, J.E., Stein, J.A. \& Gamber, J.H. 1994: Graphic correlation and sequence stratigraphy in the Palaeogene of NW Europe. Journal of Micropalaeontology 13, 55-80

Pedersen, G.K. \& Surlyk, F. 1983: The Fur Formation, a Late Paleocene ash-bearing diatomite from northern Denmark. Bulletin of the Geological Society of Denmark 32, 43-65.

Rasmussen, E.S. 2004: The interplay between true eustatic sea-leve changes, tectonics, and climate changes: what is the dominating factor in sequence formation of the Upper Oligocene - Miocene succession in the eastern North Sea Basin, Denmark? Global and Planetary Change 41, 15-30.

Thomsen, E. \& Danielsen, M. 1995: Transitional Paleocene/Eocene ashbearing diatomite in the eastern North Sea. Tertiary Research 15 , 111-120.

\section{Authors' addresses}

P.S., J.A., K.D., L.E.K. \& J.A.R., Geological Survey of Denmark and Greenland, Øster Voldgade 10, DK-1350 Copenhagen K, Denmark.

E-mail: pos@geus.dk

O.R.C. \& C.H.-C., Department of Earth Sciences, University of Aarhus, DK-8000 Arbus C, Denmark.

G.D. \& L.H., DONG, Agern Allé 24-26, DK-2970 Hørsholm, Denmark.

I.P., Statoil Norway, Forusbeen 50, N-4035 Stavanger, Norway. 